\title{
Lingkungan Fisik dan Angka Kuman Udara Ruangan di Rumah Sakit Umum Haji Makassar, Sulawesi Selatan
}

\author{
Physical Environment and Microbe Rate of Indoor Air of Makassar Hajj \\ Public Hospital, South Sulawesi
}

\author{
M. Tahir Abdullah, Buraerah Abdul Hakim
}

Fakultas Kesehatan Masyarakat Universitas Hasanuddin

\begin{abstract}
Abstrak
Udara merupakan salah satu media lingkungan tempat bakteri, virus, dan fungi hidup dan berkembang. Oleh karena mikroorganisme tersebut memerlukan berbagai persyaratan untuk tumbuh dan berkembang, faktorfaktor lingkungan fisik udara tertentu dapat berhubungan dengan angka kuman. Untuk menentukan hubungan ini, telah dilakukan studi potong lintang di ruang rawat inap pasien Rumah Sakit Umum Haji Makasar. Kualitas faktor-faktor lingkungan fisik (pencahayaan, suhu, kelembaban relatif, dan kepadatan ruangan) dan angka kepadatan kuman dalam 5 ruang rawat inap (pavilion, kelas 1, kelas 2, kelas 3, dan recovery room) diukur 3 kali (pagi, siang, dan sebelum matahari terbenam) pada 3 titik pengukuran berbeda setiap ruang. Hasilnya menunjukkan bahwa lebih dari $91 \%$ angka kuman dan $71 \%-87 \%$ kualitas lingkungan fisik tidak memenuhi kesehatan yang dipersyaratkan oleh Keputusan Menteri Kesehatan RI No. 1204/MENKES/SK/X/2004. Berdasarkan 4 faktor lingkungan fisik yang diukur, hanya kelembaban relatif yang secara langsung berhubungan dengan angka kepadatan kuman (nilai $p=0,023$ ), meskipun korelasi liniernya sangat rendah (korelasi Pearson 0,299). Sesuai dengan tingkat korelasi ini, kontribusi semua faktor lingkungan fisik kepada angka kuman hanya 14,6\% $(\mathrm{R} 2=0,382)$. Apabila disesuaikan dengan populasi standar, kontribusi ini hanya $6 \%$.
\end{abstract}

Kata kunci: Angka kuman, faktor lingkungan fisik, rumah sakit umum haji

\footnotetext{
Abstract

Air is an environmental medium where microbe such as bacteria, viruses, and fungi can live and may infect exposed people. As the microbes require appropriate condition to live and grow, particular physical environment of air may associate with microbial density rate. To determine this association, a cross-sectional study has been conducted in in-patient wards of Makassar Public Hospital of Hajj. Quality of physical environment factors (lighting, temperature, relative humidity, and room density) and microbial density rate of indoor air in five in-patient wards (pavilion, class 1, class 2, class 3 , and
}

recovery room) were measured three times (morning, afternoon, and before sunset) at three different sampling sites of each room. The results show that more than $91 \%$ microbe rate and $71 \%-87 \%$ quality of physical environmental factors do not comply with the health requirements as regulated in the Ministry of Health Decision of 1204/MENKES/ SK/X/2004. Of four physical environmental factors quantified, only relative humidity is associated directly with the microbe rate $(p=0,023)$, although its linear correlation is very low (Pearson correlation 0,299). Correspondingly, contribution of all physical environmental factors to the microbe rate is only $6 \%(R 2=0,382)$. Adjusted to the population standard, this contribution is only $6 \%$.

Key words: Physical environment factor, microbe rate, hajj public hospital

\section{Pendahuluan}

Udara merupakan komponen penting pernafasan untuk kelangsungan hidup manusia dan berbagai mahluk hidup yang lain. Komposisi kimiawi, biologis, dan fisik udara berpengaruh langsung terhadap kualitas pernapasan. Udara yang lebih banyak kontaminan berbagai bahan seperti nitrogen, gelombang elektromagnetik, dan gelombang mikro (microwave) dapat mempengaruhi kesejahteraan manusia. Udara yang menyelimuti bumi terdiri dari sekitar $78 \%$ nitrogen, $21 \%$ oksigen, $0,9 \%$ argon, $0,03 \%$ karbon dioksida, dan sejumlah kecil gas-gas lain seperti neon, helium, dan metana. ${ }^{1}$ Aktivitas manusia dapat mengubah komposisi kimia udara sehingga jumlah spesi dan konsentrasi zat-zat kimia dapat bertambah, terutama apabila aktivitas tersebut dilakukan di dalam ruangan dengan sirkulasi udara yang buruk. Kualitas

Alamat Korespondensi: M. Tahir Abdullah, Bagian Biostatistik FKM Universitas Hasanuddin, Jl. Perintis Kemerdekaan Km. 10, Tamalanrea, Makassar, Hp.082196436535,e-mail: mtahirabd@yahoo.com 
udara dalam ruang tidak hanya dipengaruhi oleh pencemaran kimia tetapi juga oleh faktor lingkungan fisik seperti suhu dan kelembaban. ${ }^{2}$

Rumah sakit sebagai tempat pelayanan kesehatan bagi masyarakat harus memiliki ruang rawat inap yang memenuhi syarat kesehatan, baik kualitas udaranya, konstruksinya maupun fasilitasnya. Di dalam ruangan yang tidak memenuhi syarat kesehatan, penyakit dapat menular melalui peralatan, bahan-bahan yang digunakan, makanan dan minuman, petugas kesehatan, dan pengunjung. Untuk mencegah penularan penyakit, Menteri Kesehatan mensyaratkan agar udara di dalam ruang rawat harus bebas kuman patogen dengan angka total kuman tidak lebih dari 500 koloni $/ \mathrm{m}^{3}$ udara. $^{3}$

Namun, persyaratan kualitas udara ruang rawat tersebut masih belum sepenuhnya terpenuhi. Misalnya, di Rumah Sakit Khusus Penyakit Menular Jakarta ditemukan bahwa dari 167 spesimen hapus tangan dan kuku petugas yang diperiksa terdapat $85,1 \%$ yang tidak steril yang mengandung $31,6 \%$ kuman batang berspora; 17,9\% bakteri Coliform; 12,9\% Staphylococcus epidermidis; 7,9\% Pseudomonas aeruginosa; 7,3\% Clostridium spp.; 6,2\% Klebsiella spp.; 5,1\% Streptococcus haemolyticus; 4,5\% Clostridium welchii; $2,8 \%$ Proteus spp.; 2,3\% E. coli; 1,1\% Staphylococcus aureus; dan $0,6 \%$ Pseudomonas spp. ${ }^{4}$

Penularan mikroorganisme kepada manusia terjadi dengan mekanisme tertentu, misalnya dengan tiupan angin, tetesan air atau droplet, percikan batuk atau bersin, percakapan, dan kontak dengan permukaan tanah. ${ }^{5}$ Di rumah sakit, mekanisme penularan ini berpotensi menimbulkan infeksi nosokomial yang berujung pada kemungkinan infeksi endemik atau epidemik. ${ }^{6}$ Misalnya, dari 285 jenis infeksi di Rumah Sakit Khusus Penyakit Menular Jakarta, infeksi nosokomial saluran kemih menempati urutan teratas $(15,9 \%)$, disusul bakteremia $(10,8 \%)$, saluran pernapasan bawah $(4,7 \%)$, saluran pencernaan $(2,6 \%)$, kulit $(2,4 \%)$, selaput lendir mulut $(1,4 \%)$, dan saluran pernapasan atas $(0,6 \%){ }^{7}$

Di Rumah Sakit Umum Haji (RSUH) Makassar, jumlah pasien rawat inap dalam 3 tahun terakhir meningkat dari 3.972 orang tahun 2000 menjadi 4.022 orang tahun 2001 dan 4.408 orang tahun 2002. Sejalan dengan peningkatan jumlah pasien, frekuensi pemakaian tempat tidur dalam suatu periode tertentu (bed occupancy rate, BOR) berfluktuasi dari $51,74 \%$ tahun 2000 menjadi $48,29 \%$ tahun 2001 dan 50,43\% tahun 2002. Di rumah sakit ini, rasio jumlah pasien terhadap luas lantai ruangan tidak memenuhi syarat kesehatan.

Jumlah pasien yang terus meningkat dan rasio jumlah pasien terhadap luas lantai ruangan yang tidak memenuhi syarat kesehatan dapat menurunkan kualitas udara ruang rawat inap. Salah satu indikator kualitas udara da- lam ruang yang rendah adalah angka kuman yang tinggi. Untuk memastikan hal ini, pada tahun 2005 di beberapa ruang rawat RSUH Makassar telah diukur angka kuman dan faktor-faktor lingkungan fisik udara dalam ruang rawat inap. Penelitian ini bertujuan untuk mengetahui hubungan faktor-faktor lingkungan fisik dengan angka kuman di dalam ruang rawat inap sehingga dapat disarankan upaya-upaya pengendaliannya.

\section{Metode}

Penelitian ini menggunakan rancangan cross sectional. Lima ruang rawat inap (paviliun, kelas I, kelas II, kelas III, recovery room) dipilih sebagai subjek dan angka kuman udara dan 4 parameter lingkungan fisik (pencahayaan, suhu, kelembaban, dan kepadatan hunian) ditetapkan sebagai unit observasi. Di dalam setiap ruang rawat inap, angka kuman dan parameter lingkungan fisik diukur pada 3 titik pengamatan, masingmasing dengan 3 kali pengukuran (pagi, tengah hari, sebelum matahari terbenam) sehingga untuk setiap ruangan dihasilkan 9 data parameter lingkungan fisik dan 9 data angka kuman udara. Pencahayaan diukur dengan luxmeter atau lightmeter, suhu diukur dengan termometer, kelembaban relatif diukur dengan higrometer, kepadatan hunian dihitung sebagai luas ruangan $\left(\mathrm{m}^{2}\right)$ per orang, dan angka kuman diukur dengan Biotest RCS Sentrifugal Air Sampler menggunakan media biakan agar strip (GK-A No. 941 100) yang dinyatakan sebagai jumlah koloni per $\mathrm{m}^{3}$ udara. Kualitas lingkungan fisik dan angka kuman udara diukur menurut prosedur Standar Operasional Pengambilan dan Pengukuran Sampel Kualitas Udara Ruangan Rumah Sakit. ${ }^{8}$ Data angka kuman dan kualitas lingkungan fisik yang dihasilkan dikategorikan sebagai memenuhi syarat (MS) dan tidak memenuhi syarat (TMS). ${ }^{3}$ Selanjutnya, dikembangkan tabel silang antara kualitas lingkungan fisik dengan angka kuman udara untuk mendapatkan faktorfaktor lingkungan fisik yang berhubungan dengan angka kuman. Hubungan tersebut dianalisis dengan uji Pearson dan regresi ganda.

\section{Hasil}

Ruang rawat yang kualitas mikroba udaranya paling baik adalah recovery room (RR), walaupun persentasenya masih sangat rendah. Di ruang rawat RR, dari 9 kali pengukuran angka kuman pada 3 titik pengamatan dalam 3 waktu berbeda hanya ada 2 hasil yang memenuhi syarat. Secara keseluruhan, hanya $<9 \%$ dari 45 kali pengukuran angka kuman yang memenuhi syarat. Angka kuman di ruang kelas II tidak lebih baik daripada angka kuman di kelas III, sementara angka kuman di kelas III sama dengan angka kuman di kelas I. Angka kuman di kelas II ternyata sama buruknya dengan angka kuman di paviliun yang $100 \%$ tidak memenuhi syarat (Lihat Tabel 1). 
Tabel 1. Angka Kuman Udara di 5 Ruang Rawat Inap

\begin{tabular}{|c|c|c|c|c|}
\hline \multirow{3}{*}{ Ruang Rawat } & \multicolumn{4}{|c|}{ Angka Kuman Udara ${ }^{a}$} \\
\hline & \multicolumn{2}{|c|}{ TMSb (> 500 koloni/ $/ \mathrm{m}^{3}$ udara) } & \multicolumn{2}{|c|}{ MSc $\left(<500 \mathrm{koloni} / \mathrm{m}^{3}\right.$ udara $)$} \\
\hline & $\mathbf{n}$ & $\%$ & $\mathbf{n}$ & $\%$ \\
\hline Paviliun & 9 & 100,0 & 0 & 0,0 \\
\hline Kelas I & 8 & 88,9 & 1 & 11,1 \\
\hline Kelas II & 9 & 100,0 & 0 & 0,0 \\
\hline Kelas III & 8 & 88,9 & 1 & 11,1 \\
\hline Recovery Room (RR) & 7 & 77,8 & 2 & 22,2 \\
\hline Total seluruh ruang rawat & 41 & 91,1 & 4 & 8,9 \\
\hline
\end{tabular}

Keterangan :

${ }^{a}$ Mengacu Keputusan Menteri Kesehatan RI No. 1204/MENKES/SK/X/2004 tentang

Persyaratan Kesehatan Lingkungan Rumah Sakit,

${ }^{b}$ Tidak memenuhi syarat,

$c_{\text {Memenuhi syarat }}$

Tabel 2. Angka Kuman dan Kualitas Lingkungan Fisik Udara

\begin{tabular}{|c|c|c|c|c|c|c|c|}
\hline \multirow{3}{*}{$\begin{array}{l}\text { Kualitas Lingkungan Fisik Standar } \\
\text { Pencahayaan (100-200 lux) }\end{array}$} & \multirow{3}{*}{$\begin{array}{c}\begin{array}{c}\text { Memenuhi } \\
\text { Syarat }\end{array} \\
\text { Tidak }\end{array}$} & \multicolumn{4}{|c|}{ Angka Kuman Udara ${ }^{a}$} & \multirow{2}{*}{$\begin{array}{c}\text { Total Lingkungan } \\
\text { Fisik MS }\end{array}$} & \multirow{2}{*}{$\begin{array}{r}\text { Kualitas } \\
\text { TMS + }\end{array}$} \\
\hline & & \multicolumn{2}{|c|}{$\begin{array}{c}\text { TMS }^{\mathrm{b}} \\
\left(>500 \mathrm{koloni} / \mathrm{m}^{3}\right)\end{array}$} & \multicolumn{2}{|c|}{$\begin{array}{c}\text { TMS }^{\mathrm{c}} \\
\left(<500 \mathrm{koloni} / \mathrm{m}^{3}\right)\end{array}$} & & \\
\hline & & 31 & 96,9 & 1 & 3,1 & 32 & 71,1 \\
\hline & $\mathrm{Ya}$ & 10 & 76,9 & 3 & 23,1 & 13 & 28,9 \\
\hline \multirow{2}{*}{ Suhu ruangan $\left(22-27^{\circ} \mathrm{C}\right)$} & Tidak & 25 & 92,6 & 2 & 7,4 & 27 & 60 \\
\hline & Ya & 16 & 88,9 & 2 & 11,1 & 18 & 40 \\
\hline \multirow[t]{2}{*}{ Kelembaban $(40-50 \%)$} & Tidak & 36 & 94,7 & 2 & 5,3 & 38 & 84,4 \\
\hline & Ya & 5 & 71,4 & 2 & 28,6 & 7 & 15,6 \\
\hline \multirow[t]{2}{*}{ Kepadatan hunian (> $10 \mathrm{~m}^{2}$ /orang) } & Tidak & 37 & 94,9 & 2 & 5,1 & 39 & 86,7 \\
\hline & $\mathrm{Ya}$ & 4 & 66,7 & 2 & 33,3 & 6 & 13,3 \\
\hline
\end{tabular}

Persentase kualitas lingkungan fisik yang tidak memenuhi syarat sebanding dengan persentase angka kuman yang tidak memenuhi syarat. Itu berarti bahwa makin tinggi proporsi kualitas lingkungan yang tidak memenuhi syarat, makin tinggi pula angka kuman yang tidak memenuhi syarat. Kontribusi terbesar faktor lingkungan fisik terhadap angka kuman adalah kepadatan hunian, disusul kelembaban, pencahayaan, dan suhu ruang (Lihat Tabel 2).

Kelembaban berhubungan secara signifikan dengan angka kuman (nilai $\mathrm{p}=0,023$ ), walaupun korelasi linier hanya 0,299 . Sementara itu, analisis korelasi berganda memberikan nilai $\mathrm{R}=0,382$ dan $\mathrm{R}^{2}=0,146$. Ini berarti, korelasi linier seluruh faktor lingkungan fisik dengan angka kuman hanya 0,382 ; sedangkan pengaruh 4 faktor lingkungan fisik terhadap angka kuman hanya 14,6\%. Bila disesuaikan dengan nilai populasi standar, besar kontribusi keempat faktor lingkungan fisik terhadap angka kuman hanya 6\% (Lihat Tabel 3).

Berdasarkan 4 faktor lingkungan fisik hanya kelembaban yang memberi kontribusi langsung kepada angka kuman (nilai $p=0,023$ ). Pencahayaan, suhu, dan kepadatan hunian tidak mempunyai kontribusi langsung kepada angka kuman ( $p>0,05$ untuk ketiga faktor lingkungan fisik). Namun, ketiga faktor lingkungan fisik itu saling berkorelasi secara signifikan, yaitu kepadatan hunian dengan suhu (nilai $p=0,000$ ), kepadatan hunian dengan pencahayaan (nilai $\mathrm{p}=0,001$ ), dan pencahayaan dengan kelembaban (nilai $\mathrm{p}=0,022$ ). Sementara itu, pencahayaan hampir signifikan berkorelasi dengan suhu 
Tabel.3 Korelasi Faktor Lingkungan Fisik dengan Angka Kuman Udara di 5 Ruang Rawat

Rumah Sakit Umum Haji Makassar Sulawesi Selatan Tahun 2005

\begin{tabular}{lccc}
\hline \multirow{2}{*}{ Faktor Lingkungan Fisik } & \multicolumn{3}{c}{ Angka Kuman Udara } \\
\cline { 2 - 4 } & Jumlah & Pearson Correlation & Signifikansi (p) \\
\hline Pencahayaan & 45 & 0,190 & 0,106 \\
Suhu & 45 & 0,011 & 0,472 \\
Kelembaban & 45 & 0,299 & 0,023 \\
Kepadatan hunian & 45 & 0,080 & 0,301 \\
\hline
\end{tabular}

Tabel 4. Matriks Korelasi Pearson Lingkungan Fisik dan Angka Kuman di 5 Ruang Rawat Rumah Sakit Umum Haji Makassar Sulawesi Selatan Tahun 2005

\begin{tabular}{|c|c|c|c|c|c|}
\hline Pearson Correlation & Angka Kuman & Pencahayaan & Suhu & Kelembaban & Kepadatan Hunian \\
\hline Angka kuman & 1,000 & 0,190 & 0,011 & 0,299 & 0,080 \\
\hline Pencahayaan & 0,190 & 1,000 & 0,245 & 0,302 & 0,468 \\
\hline Suhu & 0,011 & 0,245 & 1,000 & 0,237 & 0,713 \\
\hline Kelembaban & 0,299 & 0,302 & 0,237 & 1,000 & 0,078 \\
\hline Kepadatan hunian & 0,080 & 0,468 & 0,713 & 0,078 & 1,000 \\
\hline \multicolumn{6}{|l|}{ Signifikansi (1-tailed) } \\
\hline Angka kuman & - & 0,106 & 0,472 & 0,023 & 0,301 \\
\hline Pencahayaan & 0,106 & - & 0,053 & 0,022 & 0,001 \\
\hline Suhu & 0,472 & 0,053 & - & 0,058 & 0,000 \\
\hline Kelembaban & 0,023 & 0,022 & 0,058 & - & 0,305 \\
\hline Kepadatan hunian & 0,301 & 0,001 & 0,000 & 0,305 & - \\
\hline
\end{tabular}

(nilai $\mathrm{p}=0,053$ ) dan suhu dengan kelembaban (nilai $\mathrm{p}=$ 0,058) (Lihat Tabel 4).

\section{Pembahasan}

Udara tidak mempunyai flora alami, ${ }^{9}$ sehingga bukan habitat yang baik bagi mikroba. Mikroba patogen di udara hanya merupakan kontaminan yang bersumber dari tetesan air liur atau partikel yang berasal dari batuk atau bersin penderita penyakit infeksi. Oleh sebab itu, mikroba di udara hanya bersifat sementara yang mengapung dan terbawa oleh debu. Kualitas lingkungan fisik udara dalam ruang merupakan salah satu faktor penting yang menentukan keberadaan mikroba di udara.

Penelitian di RSUH Makassar ini telah berhasil mengukur angka kuman dalam ruang rawat inap secara kuantitatif dan menemukan korelasi angka kuman dengan pencahayaan, suhu, kelembaban, dan kepadatan hunian. Angka kuman udara dan keempat faktor lingkungan fisik ini merupakan sebagian dari beberapa Persyaratan Kesehatan Lingkungan Rumah Sakit yang diatur oleh Menteri Kesehatan. ${ }^{3}$ Hasil penelitian ini menunjukkan bahwa kelembaban merupakan faktor lingkungan fisik terbesar yang bertanggung jawab langsung atas keberadaan kuman di dalam ruang rawat.
Faktor lingkungan fisik lainnya (pencahayaan, suhu, dan kepadatan hunian) tidak berkorelasi langsung dengan angka kuman tetapi berhubungan dengan kelembaban. Kepadatan hunian berpengaruh terhadap suhu dengan nilai $p=0,000$ (Lihat Tabel 4). Secara teoritis, suhu dapat mempengaruhi kelembaban. Jadi, secara tidak langsung suhu dan kepadatan hunian juga berpengaruh terhadap angka kuman.

Selain disebabkan oleh faktor lingkungan fisik (in animate), keberadaan kuman di udara juga dapat diakibatkan oleh lingkungan biologis (animate) yang selalu berhubungan dengan lingkungan animate. Faktor animate penularan atau penyebaran kuman mencakup para petugas rumah sakit dan penderita yang dapat saling memindahkan kuman. Perilaku tidak sehat dan tidak bersih para petugas, pasien, dan anggota keluarga pasien yang berkunjung ke rumah sakit dapat meningkatkan laju penularan atau penyebaran kuman. Di RSUH Makassar, aturan yang membatasi kunjungan anggota keluarga pasien untuk membesuk sanak saudaranya belum ada. Akibatnya, kuman dari luar dapat masuk ke dalam lingkungan rumah sakit yang akhirnya dapat sampai ke ruang perawatan.

Pola penyebaran kuman juga dapat berasal dari luar 
ruangan dari organisme yang membusuk, tumbuhtumbuhan yang sudah mati, dan bangkai binatang. Serbuk sari jamur yang berspora dapat menjadi air borne bagi kuman-kuman dari luar dan masuk ke dalam ruangan dengan hembusan angin. Kuman juga dapat masuk ke dalam ruangan melalui perantara jentik-jentik dan serangga yang dapat menembus bangunan.

Penyebaran kuman melibatkan media lingkungan seperti udara dan vektor sebagai perantara atau kendaraan. Mikroorganisme patogen di udara, termasuk bakteri, virus, jamur dan parasit, dapat menyebabkan infeksi nosokomial. Di rumah sakit, infeksi ini dapat terjadi pada seseorang karena tertular oleh mikroorganisme dari orang lain atau oleh flora normal dari dirinya sendiri melalui persinggungan dengan makanan, udara, atau benda-benda yang tidak steril. ${ }^{10}$ Infeksi ini cenderung berjangkit secara epidemi, muncul dengan eksplosif, dan menyerang orang dalam waktu singkat. Beberapa jenis penyakit infeksi nosokomial yang pernah ditemukan antara lain streptocoleal yang disebabkan oleh bakteri Streptococcus, influenza oleh virus influenza, dan legionnaire oleh kuman legionella. ${ }^{11}$

Rumah sakit merupakan institusi pelayanan kesehatan yang di dalamnya terdapat bangunan, peralatan, manusia (petugas, pasien, dan pengunjung), dan kegiatan pelayanan kesehatan termasuk tindakan operasi yang membutuhkan sarana dan prasarana steril dari mikroorganisme patogen. Namun, selain dapat mengobati dan meningkatkan kesehatan orang-orang yang sakit, rumah sakit juga dapat menjadi sumber infeksi bila kegiatannya tidak dilaksanakan sesuai dengan persyaratan kesehatan. ${ }^{3}$ Dalam hubungannya dengan infeksi, kualitas lingkungan fisik merupakan faktor penting bagi keberadaan mikroba di ruangan-ruangan yang ada di dalam rumah sakit.

Berbagai penelitian penyakit infeksi nosokomial di rumah sakit di Amerika Serikat, Inggris, dan Kuwait menemukan jenis-jenis kuman (bakteri) seperti Escherichia coli, Klebsiella spp, Pseudomonas spp, Enterobakter spp, Proteus spp, Streptococcus spp, Acinetobacter spp, Citrobacter spp, dan Staphylococcus epidermis. Mikroba ini dapat menyebabkan infeksi nosokomial saluran kencing (INSK). ${ }^{12}$ Penelitian lain di rumah sakit di Amerika Serikat menemukan kuman penyebab penyakit infeksi nosokomial saluran pernafasan bawah (INSNB) yang umum, seperti Klebsiella sp, Staphylococcus aureus, Pseudomonasa aeruginosa, E. coli, Enterobacter sp, Streptococcus pneumonia, flora mulut anaerobik, Haemophilus influenza, virus Legionella sp, dan Aspergillus. ${ }^{7}$ Mikroorganisme yang paling banyak ditemukan di rumah sakit, khususnya di ruang-ruang perawatan intensif pada luka operasi pasien-pasien pada hari ke-3 dan ke-6 pascaoperasi adalah Klebsiella pneumonia, Staphy- lococcus aureus, Staphylococcus epidermidis, Acinetobacter calcoaciticus, Enterobacter agglomerans, Enterobacter aerogenes, Pseudomonas aeruginosa, dan Alkaligenes faecalis. ${ }^{10}$

Dalam ruang perawatan bedah RSUDP Dr. Wahidin Sudirohusodo Makassar ditemukan Staphylococcus aureus, kuman penyebab utama infeksi nosokomial yang berasal dari saluran pernapasan bagian atas. ${ }^{10}$ Kuman ini ditemukan pada tangan, hidung, dan tenggorokan perawat yang dapat berperan sebagai sumber penularan. Selain $S$. aureus ditemukan juga beberapa kuman lain seperti Pseudomonas sp, E. coli, Enterobacter sp, Proteus sp, Klebsiella sp, dan Bacillus sp. ${ }^{5}$

Hasil penelitian tersebut menunjukkan bahwa rumah sakit merupakan tempat penyebaran kuman, terutama dari orang sakit atau carrier ke orang sehat (dari pasien ke petugas atau dari petugas ke pasien dan dari pasien ke pengunjung atau sebaliknya). Oleh karena itu, angka kuman di ruang rawat RSUH Makassar yang lebih dari 91\% tidak memenuhi syarat kesehatan tidaklah mengejutkan. Sayangnya, dalam penelitian ini jenis-jenis kuman tidak diidentifikasi sehingga dari mana asalnya tidak dapat diketahui. Penelitian ini belum dapat menjelaskan mengapa angka kuman di ruang rawat kelas III sama dengan angka kuman di kelas I. Penelitian ini juga belum dapat menerangkan mengapa angka kuman di kelas II sama buruknya dengan angka kuman di paviliun yang $100 \%$ tidak memenuhi syarat. Sterilisasi dan desinfeksi ruangan dan peralatannya dapat menurunkan angka kuman ruangan.

Baru-baru ini Ajizah, Thihana, dan Mirhanuddin, 13 menemukan bahwa ekstrak kayu ulin (Eusideroxylon zwageri $\mathrm{T}$ et $\mathrm{B}$ ) terbukti mampu menghambat pertumbuhan bakteri Staphylococcus aureus. Efek ini diduga karena kayu ulin mengandung alkaloid, flavonoid, triterpenoid, tanin, dan saponin. Penemuan ini memberi harapan bahwa desinfeksi tidak hanya dapat dilakukan dengan zat-zat kimia sintetis tetapi juga dengan bahanbahan alam (natural products). Selama ini di kalangan masyarakat Banjarmasin, air rendaman kayu ulin biasa digunakan untuk mengobati sakit gigi. ${ }^{13}$ Studi in vitro Ajizah, Thihana, dan Mirhanuddin ini mengonfirmasi bahwa kayu ulin dapat menghambat pertumbuhan kuman-kuman yang terdapat di dalam mulut seperti Streptococcus mutans, Streptococcus viridans, Staphylococcus epidermidis, Staphylococcus pneumoniae, dan Staphylococcus aureus, ${ }^{9}$ secara efektif. Penggunaan kayu ulin sebagai mebel dalam ruang rawat mungkin dapat menurunkan angka kuman udara.

Ruang rawat yang kurang steril berpotensi menimbulkan infeksi nosokomial seperti yang terjadi di beberapa rumah sakit di tanah air dan luar negeri. Bila hal ini terjadi, konsekuensinya bukan saja diderita oleh pasien secara medis tetapi juga kerugian besar 
secara ekonomi. Infeksi nosokomial pada umumnya akan menyebabkan penyakit yang parah dan waktu sembuh yang lama sehingga biaya rawat juga semakin mahal.

\section{Kesimpulan}

Kelembaban ruang rawat RSUH Makassar berhubungan langsung secara bermakna dengan angka kuman udara, walaupun korelasi linier-nya sangat rendah. Pencahayaan, suhu, dan kepadatan hunian memberi kontribusi secara tidak langsung kepada angka kuman melalui kelembaban udara. Proporsi kualitas lingkungan fisik yang tidak memenuhi syarat sebanding dengan proporsi angka kuman yang tidak memenuhi syarat menurut Persyaratan Kesehatan Lingkungan Rumah Sakit yang diatur dalam Keputusan Menteri Kesehatan RI No. 1204/MENKES/SK/X/2004.

\section{Saran}

Pengelola RSUH Makassar disarankan agar memodifikasi setiap ruang rawat inap sehingga kelembaban dan faktor-faktor lingkungan fisik lainnya yang berhubungan dengan kelembaban (suhu dan kepadatan hunian) memenuhi persyaratan kesehatan lingkungan rumah sakit. Pemenuhan persyaratan kualitas lingkungan fisik ini diharapkan dapat menurunkan angka kuman udara sehingga infeksi nosokomial dapat dicegah.

\section{Daftar Pustaka}

1. Fardiaz S. Polusi air dan udara. Yogyakarta: Kanisius; 1992.

2. Rendra S, Pudjiastuti L, Sentosa HR. Kualitas udara dalam ruang. Jakarta: Direktorat Jenderal Pendidikan Tinggi Departemen Pendidikan dan Kebudayaan RI; 1998.

3. Departemen Kesehatan RI. Keputusan menteri kesehatan republik Indonesia nomor 1204/MENKES/SK/X/2004 tentang persyaratan kesehatan lingkungan rumah sakit. Jakarta: Departemen Kesehatan RI; 2004.

4. Janas S, Punjabi NH. Pencemaran kuman di lingkungan Rumah Sakit Khusus Penyakit Menular Jakarta. Buletin Penelitian Kesehatan. 1992; 22 (2).

5. Baharuddin. Pola bakteri dan kepekaannya terhadap beberapa antibiotika di ruang bedah sentral RSUP Dr. Wahidin Sudirohusodo Makassar. Bandung: Universitas Padjadjaran; 2002.

6. Soeroso L. Petunjuk praktikum mikrobiologi lingkungan. Purwokerto: PAM SKL; 1993

7. Janas S, Punjabi NH. Infeksi nosokomial di Rumah Sakit Khusus Penyakit Menular Jakarta. Buletin Penelitian Kesehatan. 1992; 22 (2).

8. Departemen Kesehatan RI. Keputusan menteri kesehatan republik Indonesia nomor 1335/MENKES/SK/X/2002 tentang standar operasional pengambilan dan pengukuran sampel kualitas udara rumah sakit. Jakarta: Departemen Kesehatan RI; 2002.

9. Volk WA, Wheeler MF. Mikrobiologi dasar. Ed. 5. Jakarta: Erlangga; 1990.

10. Adysaputra A, Rauf MA, Bahar B. Patterns and prevalence of nosocomial microbial infection from intensive care unit patients, Wahidin Sudirohusodo Hospital, Makassar. The Indonesian Journal of Medical Science. 2009; 2 (2): p. 67-70.

11. Pelezar MJ. Dasar-dasar mikrobiologi 2. Jakarta: University of Indonesia Press; 1993.

12. Musadad A. Pola bakteri dan kepekaannya terhadap beberapa antibiotika di ruang bedah sentral RSUP Dr. Wahidin Sudirohusodo Makassar. Editor oleh Baharuddin. Bandung: Universitas Padjadjaran; 2002.

13. Ajizah A, Thihana, Mirhanuddin. Potensi ekstrak kayu ulin (eusideroxylon zwageri t et b) dalam menghambat pertumbuhan bakteri staphylococcus aureus secara in vitro. Bioscientiae. 2007; 4 (1): p. 37-42. 